\title{
Effects of predation and disturbance by ophiuroids on soft-bottom community structure in Oslofjord: results of a mesocosm study*
}

\author{
William G. Ambrose Jr \\ Department of Biology, East Carolina University, Greenville, North Carolina 27858, USA
}

\begin{abstract}
Effects of 2 ophiuroids (Ophiura affinis and $O$ albida) on the structure of a soft-bottom community dominated by polychaetes were examined in a mesocosm. These 2 ophiuroids are common members of the soft-bottom community at $30 \mathrm{~m}$ depth in Oslofjord, Norway, where together they reach a density of $276 \mathrm{ind} . \mathrm{m}^{-2}$. The following 4 treatments were established and sampled after 6 and $12 \mathrm{wk}$ : ophiuroid removal, ambient ophiuroid density, elevated ophiuroid density ( 3.6 times ambient), and an unmanipulated control. Polychaetes inhabiting the top $3 \mathrm{~cm}$ of the sediment were $30 \%$ and surfacedwelling, deposit-feeding, sedentary infauna $40 \%$ less abundant in the presence of ophiuroids than in their absence. Ophiuroids had no effect on abundances of taxa living deeper than $3 \mathrm{~cm}$. No significant differences in infaunal abundances were detected among any of the treatments containing ophiurioids. The ophiuroid species manipulated in this study disturb the top $1 \mathrm{~cm}$ of the sediment while foraging. This behavior probably accounts for the specific effect of these ophiuroids on surface-dwelling taxa. Sediment traps collected significantly more surface sediment in the presence of ophiuroids than in their absence. A multivariate comparison of infaunal abundances among treatments indicated a slight effect of these ophiuroids on infaunal community structure. The ophiuroids also affected species diversity (Shannon-Wiener Index) which was higher in the absence of ophiuroids than in the elevated ophiuroid density treatment after $12 \mathrm{wk}$
\end{abstract}

\section{INTRODUCTION}

The role of large mobile epibenthic predators in determining the distribution and abundance of organisms living in marine soft-bottom communities has been investigated since early this century and recognized as an important organizing force in many communities for over a decade (see reviews by Peterson 1979, 1991, Baird et al. 1985, Reise 1985, Wilson 1991). By contrast, the importance of smaller predators, many of which spend most of their life buried in the sediment, in structuring soft-bottom communities has received far less attention. Manipulative experiments with these less conspicuous, infaunal predators have revealed that they can affect infaunal densities and the spatial and temporal distribution of their prey (see review by Ambrose 1991). Investigations on the role of

\footnotetext{
- Contribution No. 31 from the Marine Research Station Solbergstrand, Norway
}

infaunal predators in structuring soft-bottom communities have, however, concentrated on very few taxa and been conducted almost exclusively in intertidal, unvegetated, muddy habitats.

Ophiuroids live subtidally worldwide, often reaching extremely high densities in soft-bottom communities. Epibenthic ophiuroids can occur in beds with densities of thousands of individuals per square meter (Aronson 1989, Fujita \& Ohta 1989, 1990). Infaunal ophiuroids can also occur in equally dense assemblages (Rosenberg \& Möller 1979, Muus 1981). Many of the taxa which form these dense beds are suspension feeders (e.g. some amphiurids), but ophiuroids are opportunistic feeders and many taxa are predator-scavengers and deposit feeders (Warner 1982). High densities of ophiurioids in Northern European waters led Thorson (1958) to speculate on the fate of settling larvae encountering ophiuroid beds and question the role of omnivorous ophiuroids in structuring soft-bottom communities. While many studies have investigated the 
distribution, abundance, and feeding behavior of ophiuroids in a wide variety of marine communities, only one study I know of has experimentally assessed the effect of an ophiuroid on infaunal abundances (Crowe et al. 1987).

Ophiuroids may generally have escaped the manipulative fervor of marine ecology's last decade because they only occur subtidally, and except for some relatively sedentary taxa, are extremely mobile and therefore difficult to manipulate. I made use of a mesocosm to manipulate the densities of 2 ophiuroid species, Ophiura affinis and $O$. albida, which are common in the softbottom community of Oslofjord. Ophiura species are primarily predators, but they have been recorded to scavenge and surface deposit-feed (Warner 1982). These 2 species live partially buried in the top $1 \mathrm{~cm}$ of sediment and forage on or near the sediment surface. While foraging, they disturb the surface sediment, a process recognized as important in structuring softbottom communities (Peterson 1979, Wilson 1991).

The inadequacy of functional groups (Jumars \& Nowell 1984) makes modeling the effects of bioturbation on taxa with different mobilities, living positions, and feeding strategies difficult (Posey 1987, Wilson 1991). Nevertheless, the mobility-mode functional group approach does predict that larger species which significantly modify the sediment, such as the Ophiura species I manipulated, negatively affect the abundance of smaller, sedentary taxa (Posey 1987, 1990). In addition, the activity of these ophiuroids is likely to have a more deleterious effect on surface-dwelling than deep-dwelling taxa (Ambrose 1984a, 'Olafsson \& Elmgren 1991). In this paper, I present the results of addition and removal experiments designed to test the prediction that predation and disturbance by these 2 Ophiura species reduce the abundance of surfacedwelling, sedentary taxa. I also examine the effects of these ophiuroids on soft-bottom community structure in general.

\section{METHODS}

Description of mesocosm. The mesocosm I used is part of the NIVA (Norwegian Institute for Water Research) Marine Research Station at Solbergstrand located approximately $5 \mathrm{~km}$ south of Dröbak on the east side of Oslofjord. A detailed description of the mesocosm, the method of sediment transplantation, and an assessment of its performance as a mimic for subtidal soft-bottom communities can be found in Berge et al. (1986). Briefly, the mesocosm consists of 6 independent basins each $28 \mathrm{~m}^{2}$ and capable of holding a large number of boxes containing sediment. Water from $42 \mathrm{~m}$ deep in adjacent Oslofjord is delivered to each basin through a series of holes placed along a pipe suspended horizontally $60 \mathrm{~cm}$ above the basins' bottom. All basins are covered. Light is supplied by incandescent bulbs and the light intensity and the light/dark cycle were regulated to mimic conditions at 30 to $40 \mathrm{~m}$ depth during the time of the experiment.

Sediment for the experiment was collected from $32 \mathrm{~m}$ deep at Björnhodebukta $\left(59^{\circ} 42.8^{\prime} \mathrm{N}, 10^{\circ} 32.2^{\prime} \mathrm{W}\right)$, a site inside Oslofjord's sill. The sediment at this site is largely silt and clay and supports a diverse infaunal community (see Valderhaug \& Gray 1984 for a detailed physical and biological description of this site; Gee et al. 1985 and Warwick et al. 1986 provide a description of the meiofaunal community). Sediment cores were collected with a $0.25 \mathrm{~m}^{2}$ modified USNEL spade corer (same as a Mark III box core; Ocean Instrument, Inc., San Diego, CA, USA) fitted with a PVC liner. After sampling and as the liners were removed from the box core, a bottom plate was slid under the liner creating a box of sediment. The boxes contained $28 \mathrm{~cm}$ of sediment with $12 \mathrm{~cm}$ of overlying water. They were carefully transported from the sample site to the mesocosm, a distance of about $12 \mathrm{~km}$, within a few hours of collection.

Experimental design. Interpretation of the results of manipulative experiments with infauna is often complicated by an inability to establish a full range of density treatments of experimental organisms. Because selective removal of infauna is usually impossible without destroying the sediment structure and infaunal community, manipulative experiments with infauna usually involve either addition of organisms to the natural community or removal of all infauna by defaunating sediment followed by additions. Even when a full range of density treatments is established following the removal of all infauna, low density treatments are often reinvaded by experimental organisms, reducing density differences among treatments. In the mesocosm, no immigration of adults into experimental plots occurred. In addition, the manipulated ophiuroids spend some time on the sediment surface and are, therefore, more amenable to manipulation than if they were wholly infaunal. Thus, some of the problems of manipulative experiments with infauna were avoided. Consequently, I was able to establish and maintain for the experiment's duration the following treatments: (1) ophiuroid removal (all Ophiura affinis and $O$. albida removed), treatment 'Ox': (2) ambient ophiuroid density (all ophiuroids removed and re-added to boxes at ambient density) ' $1 x^{\prime}$; (3) high ophiuroid density (all ophiuroids removed and re-added to boxes at 3.6 times natural density) ' $\mathrm{H}$ '; and (4) control boxes (unmanipulated boxes containing an ambient density of ophiuroids) ' $\mathrm{C}$ '. Although adult $O$. albida are larger than adult $O$. affinis and move a little slower, these 2 Ophiura species have very similar living positions in the sediment and foraging behaviors, 
and consequently their removal was treated as a single treatment.

Twelve boxes of sediment were collected on 18 April 1985 and placed in 1 mesocosm basin in 3 rows of 4 boxes each. Treatments were randomly assigned to boxes with each treatment represented by 3 replicate boxes. The following day, the water level in the basin was lowered to just below the upper lip of the boxes. and I began the process of removing ophiuroids. Ophiura affinis and $O$. albida spend much of their time buried just below the sediment surface. When they forage, however, they move on the sediment surface by lifting their disk and pushing with their arms. During the brief instant their disk is elevated, it is possible to insert a probe under the disk and lift them into the water column where they can be collected. This method causes minimal, if any, disturbance of the sediment surface and was used to remove all $O$. albida and $O$. affinis from all boxes except control boxes. Because individuals are not always active on the sediment surface, it was necessary to remove ophiuroids over several days. Ophiuroids were removed until the average number of individuals collected per removal fell below 1 per box. This process required 5 separate removals spanning $3 \mathrm{~d}$.

Ophiuroids collected were sorted by species and separated by eye into groups of small and large individuals. Boxes contained a mean of 69.3 ( $\mathrm{SE}=9.1)$ individuals of the 2 species which is equal to a density of $276 \mathrm{~m}^{-2}$. Ophiura affinis was the more abundant of the 2 species with a mean density of 65.3 ind. box ${ }^{-1}$ ( $\mathrm{SE}=$ 8.6) compared with a density of $3.4(\mathrm{SE}=0.7) \mathrm{O}$. albida box ${ }^{-1}$. These densities and the natural proportion of large and small individuals were used to establish the density treatments. The ambient density treatment received 69 individuals ( 650 . affinis and 40 . albida) while the high density treatment received 253 individuals (253 O. affinis and 15 O. albida) or 3.6 times ambient density. Ophiuroids were added to treatment boxes over a period of $3 \mathrm{~d}$ with treatments fully established on 24 April. Ophiuroids buried into the sediment immediately after addition, but within $30 \mathrm{~min}$ some individuals were observed moving normally on the sediment surface. Boxes were sampled after $6 \mathrm{wk}$ on 8 June and again after $12 \mathrm{wk}$ on 19 July.

At each sampling, 3 cores $\left(6 \mathrm{~cm}\right.$ deep $\times 13.2 \mathrm{~cm}^{2}$, $4.1 \mathrm{~cm}$ inside diameter) were taken from each box. Placement of cores was haphazard, but confined to only one half of a box for each sampling, minimizing the possibility that sampling at $6 \mathrm{wk}$ disturbed the sediment on the other half of the box sampled at 12 wk. Each core was divided into $0-3$ and $3-6 \mathrm{~cm}$ sections and the sediment placed in $10 \%$ buffered formalin with rose bengal. After several weeks in formalin, the top section was sieved on a $100 \mu \mathrm{m}$ mesh and the bottom section on $250 \mu \mathrm{m}$. The material retained on the sieves was stored in $70 \%$ isopropyl alcohol, sorted under a dissecting microscope at $12 \times$ magnification and organisms identified to the lowest taxon possible.

Sediment traps were placed in each box during the first $2 \mathrm{wk}$ of the experiment. Traps were glass vials $(1.8 \mathrm{~cm}$ inside diameter $\times 3.2 \mathrm{~cm}$ deep) pushed into the sediment until their lip was flush with the sediment surface. Two traps were placed $16 \mathrm{~cm}$ apart in the center of each box. Traps were removed after $3 \mathrm{~d}$ and replaced with new ones which were removed after 8 more days. Sediment in the traps was filtered through a millipore filter which was then dried at $60^{\circ} \mathrm{C}$ to a constant weight.

Each box was photographed at the conclusion of the experiment to assess the final density of ophiuroids. Pictures were taken with a $35 \mathrm{~mm}$ single lens reflex camera (50 mm lens) mounted $70 \mathrm{~cm}$ above the sediment surface and 2 underwater flashes. This arrangement allowed the entire surface of a box to be photographed with minimal shadows along edges. Film was observed under a dissecting microscope at $12 \times$ magnification and ophiuroids counted. This method provides an underestimate of ophiuroid density because at any time some individuals are buried too deeply to be easily visible. Assuming the proportion of buried individuals was the same among treatments, however, this method reveals relative differences in ophiuroid density among treatments.

Ophiuroids for gut analyses were collected haphazardly from boxes after the conclusion of the experiment and placed in 10\% formalin. Stomach contents were examined by flushing the oral cavity with water and examining the material flushed out under a dissecting microscope.

Statistical analyses. Abundances of common taxa (greater than $1.5 \%$ of the total number of individuals sampled at each time), major taxonomic groups, and functional groups were compared between times and among treatments. Functional groups are defined by animals' mode of feeding, feeding location, and motility (Young \& Rhoads 1971, Fauchald \& Jumars 1979, Wilson 1991). Mode of feeding was classified as: deposit feeder (ingests sediment and associated organic material), suspension feeder (removes suspended material from the water column), carnivore (feeds on live animal tissue), or omnivore (feeds on dead or live animal tissue and plant material). Location of feeding was classified as either surface if the animal feeds at the sediment-water interface or subsurface if feeding occurs below the sediment surface. Motility was classified as either motile (moves feeding location in search of food) or sedentary (remains essentially in one place to feed). Classification was based on information from Pettibone (1963), Day (1967), Abbott (1974), Fauchald \& Jumars (1979), and Barnes (1980). 
A 3-way mixed model analysis of variance (ANOVA) was used to compare densities of taxa, taxonomic groups, and functional groups among treatments and between time periods for individuals collected in the $0-3 \mathrm{~cm}$ deep fraction. In these analyses, factors were time (fixed), treatments (fixed), and boxes (nested within time $x$ treatment, random). This design assumes that sampling at $6 \mathrm{wk}$ did not influence infaunal densities at $12 \mathrm{wk}$ and that $6 \mathrm{wk}$ and $12 \mathrm{wk}$ samples can be treated independently. This is a reasonable assumption because the cores sampled a very small portion of the box, sampling was confined to half the box leaving the other side undisturbed, only 8 ophiuroids were collected from all treatments at 6 wk so experimental densities were not substantially reduced, and no change in ophiuroid behavior was observed between the time before and after the $6 \mathrm{wk}$ sampling. A StudentNewman-Keuls test was used to determine significant differences among treatment means for all significant $(\mathrm{p}<0.05)$ ANOVAs. Where an analysis indicated there was no significant difference among cores within boxes or among boxes within treatments $(p>0.25)$, then post-hoc pooling procedures (Winer 1971) were used and a new significance level determined. Where posthoc pooling yielded significant results, subsequent Student-Newman-Keuls tests used the pooled mean square error and degrees of freedom to compare differences among treatment means. In the one instance where a time $\times$ treatment interaction was significant, a Student-Newman-Keuls test was used to test for significant differences among treatment means within each time period as described by Neter et al. (1985).

The 3-6 cm fraction was only sorted for samples collected after $12 \mathrm{wk}$. Differences in infaunal abundances among treatments for organisms in this depth range were compared with a 2-way, Model I, nested ANOVA with treatments (fixed) and boxes (nested within treatments, random). Post-hoc pooling, as described above, was used where appropriate. Prior to all analyses the data were tested for homogeneity of variances using the $F_{\max }$-test and where necessary $\log _{10}(x+1)$-transformed and retested.

Only 13 of the 68 taxa collected were common enough to be included in the univariate significance tests. In order to include all the taxa sampled in a comparison of treatments, infaunal abundances in the $0-3 \mathrm{~cm}$ depth range were also compared between times and among treatments using non-metric multidimensional scaling based on the Bray-Curtis similarity index. Data were not transformed prior to this analysis. Differences among groups of samples were tested using a 2-way Analysis of Similarity (ANOSIM) as described by Clark \& Green (1988).

Species diversity (Shannon-Wiener Index), evenness $(J)$, and species richness (total number of species) were compared among treatments for each time period separately with the Kruskal-Wallis test. When this test was significant ( $p<0.05$ ), Dunn's test was used to determine significant differences among treatment means (Zar 1984). Except for tanaids at $6 \mathrm{wk}$, both univariate and multivariate tests indicated no significant differences between the $1 \times$ treatment and control, so these treatments were combined for this analysis.

The amount of sediment collected in the sediment traps was compared by first determining the average amount of sediment per trap in each box and using this average in a 2-way ANOVA with treatment and time as the main effects. A Student-Newman-Keuls test was used to compare treatment means.

\section{RESULTS}

\section{Maintenance of treatments}

Analysis of photographs of the sediment surface in each box taken at the conclusion of the experiment revealed a significant difference in the abundance of ophiuroids among treatments (1-way ANOVA; $F=$ $142.7, \mathrm{df}=3,8, p<0.001$ ) with no significant difference $(p>0.05)$ in mean abundance detected between the $1 x$ treatment $\left(\right.$ mean $=45.6$ ind. box $^{-1}, \mathrm{SE}=5.2$ ) and control (mean $=42.3$ ind. box $^{-1}, \mathrm{SE}=1.8$ ) boxes by a Student-Newman-Keuls test. No ophiuroids were observed in the $0 \times$ removal treatment and there were significantly more individuals in the elevated ophiuroid density treatment (mean $=107.3$ ind. box ${ }^{-1}, \mathrm{SE}=$ 8.8) than in the $1 \times$ treatment or the control. Although emigration of ophiurioids occurred during the experiment, the elevated ophiuroid density treatment had more than twice as many individuals as the $1 \times$ treatment or the control and the experiment tested the effects of ophiuroids on infaunal abundances under conditions in the mesocosm.

\section{Faunal response}

During sampling it was discovered that one box assigned to the $1 \times$ treatment contained rocks and gravel. This was noticeably different sediment composition from all other boxes which were predominately silt and clay. Sediment composition is known to have a strong effect on the composition and abundance of infauna (Gray 1981) and consequently this box was excluded from all analyses.

The functional groups to which taxa were assigned and their densities in the $0-3$ and 3-6 cm depth ranges are given in Table 1. Most of the individuals collected probably settled prior to sediment collection, but the 
Table 1. Abundance and functional group, for all infauna collected. Mean (SE) abundances per $13.2 \mathrm{~cm}^{2}$ core averaged over all treatments and times at 2 depths $(0-3,3-6 \mathrm{~cm})$ are presented. Functional groups refer to feeding location, preferred food type, and motility (see 'Materials and methods'): Sfc $=$ Surface forager; Sub $=$ subsurface forager $;$ Df $=$ deposit feeder; Su $=$ suspension feeder; $C=$ carnivore $\mathrm{O}=$ omnivore; $\mathrm{M}=$ motile; $\mathrm{S}=$ sedentary; Unk = unknown

\begin{tabular}{|c|c|c|c|}
\hline \multirow[t]{2}{*}{ Taxa } & \multirow[t]{2}{*}{ Functional group } & \multicolumn{2}{|c|}{ Abundance } \\
\hline & & $0-3 \mathrm{~cm}$ & $3-6 \mathrm{~cm}$ \\
\hline \multicolumn{4}{|l|}{ Polychaeta } \\
\hline \multicolumn{4}{|l|}{ Ampharetida } \\
\hline Amphicteis gunneri & SfC, Df, S & $0.02(0.02)$ & 0 \\
\hline Sosane gracilis & $\mathrm{SfC}_{1}$ Df, $\mathrm{S}$ & $0.44(0.09)$ & $0.21(0.07)$ \\
\hline Melinna cristata & $\mathrm{Sf}_{\mathrm{C}}, \mathrm{Df}, \mathrm{S}$ & $0.01(0.02)$ & 0 \\
\hline Mugga wahrbergi & $\mathrm{SfC}_{\mathrm{C}} \mathrm{Df}, \mathrm{S}$ & $0.77(0.15)$ & 0 \\
\hline Unid. Ampharetida & $S f c, D f, S$ & $0.06(0.02)$ & 0 \\
\hline \multicolumn{4}{|l|}{ Cirratulidae } \\
\hline Chaetozone setosa & Sfc, Df, S & $4.1(0.39)$ & $0.12(0.07)$ \\
\hline \multicolumn{4}{|l|}{ Cossuridae } \\
\hline Cossura longocirrata & Sub, Df, M & $1.61(0.21)$ & $1.03(1.07)$ \\
\hline \multicolumn{4}{|l|}{ Capitellidae } \\
\hline Mediomastus fragilis & Sub, Df, M & $1.09(0.015)$ & $0.36(0.11)$ \\
\hline Heteromastus filiformis & Sub, Df, M & $0.32(0.09)$ & $0.64(0.18)$ \\
\hline Unid. Capitellidae & $\mathrm{Sf}_{c}, \mathrm{Df}, \mathrm{S}$ & $0.02(0.02)$ & 0 \\
\hline \multicolumn{4}{|l|}{ Dorvilleidae } \\
\hline Ophryotrochasp. & Sfc, C/Df, M & $0.17(0.07)$ & $0.03(0.03)$ \\
\hline Schistomeringos sp. & Sfc, C/Df, M & $2.37(0.31)$ & $0.52(0.12)$ \\
\hline Unid. Dorvilleidae & Sfc, C, M & $0.06(0.02)$ & 0 \\
\hline \multicolumn{4}{|l|}{ Flabelligeridae } \\
\hline Diplocirrus glaucus & $\mathrm{Sfc}, \mathrm{Df}, \mathrm{S}$ & $0.06(0.03)$ & 0 \\
\hline Pherusa plumosa & SfC, Df, S & $0.03(0.02)$ & 0 \\
\hline Unid. Flabelligeridae & Sfc, Df, S & 0 & $0.03(0.03)$ \\
\hline \multicolumn{4}{|l|}{ Glyceridae } \\
\hline Glycera alba & Sub, C, M & $0.12(0.05)$ & $0.03(0.03)$ \\
\hline \multicolumn{4}{|l|}{ Goniadidae } \\
\hline Goniada maculata & Sub, C, M & $0.05(0.03)$ & $0.03(0.03)$ \\
\hline \multicolumn{4}{|l|}{ Hesionidae } \\
\hline Micropthalmus sp. & Sub/Sfc, C, M & $0.06(0.04)$ & $0.06(0.04)$ \\
\hline Unid. Microphthalminae & $\mathrm{Sf} \mathrm{c} / \mathrm{Sub}, \mathrm{C}, \mathrm{M}$ & 0 & $0.09(0.06)$ \\
\hline \multicolumn{4}{|l|}{ Lumbrineridae } \\
\hline Lumbrinereis fragilis & Sub, C, M & $0.15(0.04)$ & 0 \\
\hline Unid. Lumbrineridae & Sub, C, M & $0.11(0.04)$ & 0 \\
\hline \multicolumn{4}{|l|}{ Maldanidae } \\
\hline Praxillella praetermissa & Sub, Df, S & $0.02(0.02)$ & 0 \\
\hline Maldane sarsi & Sub, Df, S & $0.05(0.03)$ & 0 \\
\hline \multicolumn{4}{|l|}{ Opheliidae } \\
\hline Ophelina acuminata & Sub, Df, M & $0.03(0.03)$ & 0 \\
\hline \multicolumn{4}{|l|}{ Orbinidae } \\
\hline Scoloplos armiger & Sub, Df, M & $0.02(0.02)$ & 0 \\
\hline \multicolumn{4}{|l|}{ Paraonidae } \\
\hline Paraonis fulgens & Sub, Df, M & $0.39(0.16)$ & $0.48(0.14)$ \\
\hline P. gracilis & Sub, Df, M & $0.27(0.16)$ & $0.27(0.11)$ \\
\hline Paraonis sp. & Sub, Df, M & 0 & $0.03(0.03)$ \\
\hline Unid. Paraonidae & Sub, Df, M & $0.29(0.16)$ & 0 \\
\hline \multicolumn{4}{|l|}{ Phyllodocidae } \\
\hline Eulalia viridis & $\mathrm{SfC}_{\mathrm{C}} \mathrm{C}, \mathrm{M}$ & $0.06(0.02)$ & 0 \\
\hline Eteone longa & $\mathrm{Sfc} / \mathrm{Sub}, \mathrm{C}, \mathrm{M}$ & 0 & $0.03(0.03)$ \\
\hline \multicolumn{4}{|l|}{ Sabellidae } \\
\hline Chone infundibuliformis & Sfc, Su, S & $0.05(0.03)$ & $0.03(0.03)$ \\
\hline Jasmineira caudata & $\mathrm{Sfc}_{\mathrm{C}} \mathrm{Su}, \mathrm{S}$ & $0.02(0.02)$ & 0 \\
\hline Unid. Sabellidae & Sfc, Su, S & $0.09(0.06)$ & 0 \\
\hline
\end{tabular}


Table 1 (continued)

\begin{tabular}{|c|c|c|c|}
\hline \multirow[t]{2}{*}{ Taxa } & \multirow[t]{2}{*}{ Functional group } & \multicolumn{2}{|c|}{ Abundance } \\
\hline & & $0-3 \mathrm{~cm}$ & $3-6 \mathrm{~cm}$ \\
\hline \multicolumn{4}{|l|}{ Sigalionidae } \\
\hline Pholoe minuta & Sfc, C, M & $1.57(0.19)$ & $0.18(0.07)$ \\
\hline \multicolumn{4}{|l|}{ Sphaerodoridae } \\
\hline Ephesiella abyssorum & Sfc, Df, M & $0.03(0.03)$ & 0 \\
\hline Unid. Sphaerodoridae & Sfc, Df, M & $0.02(0.02)$ & 0 \\
\hline \multicolumn{4}{|l|}{ Spionidae } \\
\hline Prionospio malmgreni & Sfc, Df, S & $0.80(0.13)$ & $0.09(0.05)$ \\
\hline P. cirrifera & $\mathrm{SfC}_{\mathrm{C}} \mathrm{Df}, \mathrm{S}$ & $0.50(0.09)$ & $0.33(0.03)$ \\
\hline Pseudopolydora paucibranchiata & $\mathrm{Sf}_{\mathrm{c}}, \mathrm{Df}, \mathrm{S}$ & $0.72(0.15)$ & $0.03(0.03)$ \\
\hline Spiophanes kroyeri & $\mathrm{SfC}_{\mathrm{C}}$ Df, S & $0.02(0.02)$ & 0 \\
\hline \multicolumn{4}{|l|}{ Syllidae } \\
\hline Exogone verugera & $\mathrm{SfC}_{\mathrm{C}} \mathrm{C}, \mathrm{M}$ & $0.9(0.13)$ & $0.15(0.09)$ \\
\hline Sphaerosyllis tetralis & $\mathrm{Sf}_{\mathrm{C}}, \mathrm{C}, \mathrm{M}$ & $1.8(0.019)$ & $0.03(0.03)$ \\
\hline Syllides longicirrata & $\mathrm{SfC}_{1} \mathrm{C}, \mathrm{M}$ & $0.04(0.02)$ & 0 \\
\hline Typosyllis variagata & $\mathrm{Sfc}, \mathrm{C}, \mathrm{M}$ & $0.02(0.02)$ & $0.03(0.03)$ \\
\hline Uniả. Syllidae & $\mathrm{SfC}_{1}, \mathrm{C}, \mathrm{M}$ & $0.21(0.09)$ & $0.03(0.03)$ \\
\hline \multicolumn{4}{|l|}{ Terebellidae } \\
\hline Amaeana trilobata & Sfc, Df, S & $0.02(0.02\}$ & 0 \\
\hline Polycirris sp. & Sfc, Df, S & $0.03(0.02)$ & 0 \\
\hline Lanassa nordenskioldi & $\mathrm{Sfc}_{1} \mathrm{Df}, \mathrm{S}$ & $0.02(0.02)$ & 0 \\
\hline Unid. Archiannelida & Unk & $0.12(0.04)$ & 0 \\
\hline \multicolumn{4}{|l|}{ Mollusca } \\
\hline Chaetoderma nitidulum & $S f c, S u, S$ & $0.02(0.02)$ & 0 \\
\hline Thyasira sp. & $\mathrm{Sfc}, \mathrm{Su}, \mathrm{S}$ & 0 & $0.03(0.03)$ \\
\hline Bivalvia juv. & Unk & $9.04(0.69)$ & $0.15(0.06)$ \\
\hline \multicolumn{4}{|l|}{ Crustacea } \\
\hline Ostracoda & & & $0.45(0.16)$ \\
\hline Philomedes brenda & $\mathrm{SfC}_{\mathrm{C}} \mathrm{Su}, \mathrm{M}$ & $9.20(0.7)$ & $0.03(0.03)$ \\
\hline Tanaidacea & $\mathrm{Sfc}_{1} \mathrm{C}, \mathrm{M}$ & $0.77(0.12)$ & $0.45(0.31)$ \\
\hline \multicolumn{4}{|l|}{ Amphipoda } \\
\hline Haploops tubicola & $\mathrm{SfC}_{\mathrm{C}} \mathrm{Su} / \mathrm{Df}, \mathrm{S}$ & $0.54(0.12)$ & 0 \\
\hline Phthisica marina & $\mathrm{Sfc}, \mathrm{C} / \mathrm{O}, \mathrm{M}$ & $0.11(0.09)$ & 0 \\
\hline Isopoda & $\mathrm{SfC}, \mathrm{C} / \mathrm{O}, \mathrm{M}$ & 0 & $0.03(0.03)$ \\
\hline Cumacea & Sfc, Su/Df, M & $0.02(0.02)$ & 0 \\
\hline \multicolumn{4}{|l|}{ Chelicerata } \\
\hline Unid. Halacaridae & Unk & $3.6(0.4)$ & $0.21(0.11)$ \\
\hline \multicolumn{4}{|l|}{ Echinodermata } \\
\hline Amphiura filiformis & $\mathrm{Sfc}_{\mathrm{c}} \mathrm{Su}, \mathrm{S}$ & $0.03(0.02)$ & $0.03(0.03)$ \\
\hline A. chiajei & $\mathrm{Sfc}, \mathrm{Su}, \mathrm{S}$ & 0 & $0.03(0.03)$ \\
\hline Ophiura albida & $\mathrm{SfC}, \mathrm{C} / \mathrm{O}, \mathrm{M}$ & $0.02(0.02)$ & 0 \\
\hline O. affinis & Sfc, C/O, Df, M & $0.22(0.07)$ & 0 \\
\hline Unid. Sipuncula & $\mathrm{SfC}_{1} \mathrm{Df}, \mathrm{S}$ & $0.03(0.02)$ & 0 \\
\hline Unid. Priapulida & Stc, O/Df,M & $0.92(0.14)$ & 0 \\
\hline Unid. Nemerteana & SfC, C, M & $0.06(0.03)$ & $0.06(0.42)$ \\
\hline
\end{tabular}

small size of some polychaetes (less than 5 setigers) and the presence of incompletely metamorphosed individuals indicate that some settlement occurred during the experiment.

Only total polychaetes and the functional group 'Sfc, Df, S' (surface, deposit-feeding, sedentary) showed a significant treatment effect in the 3-way ANOVA (Table 2). There were significantly more polychaetes and individuals of the 'SfC Df, S' functional group in the $0 \times$ treatment than in any of the treatments containing ophiuroids (Fig. 1). Time only had a significant effect on priapulids with significantly more individuals present at 6 wk (mean $=1.27$ ind. core ${ }^{-1}, \mathrm{SE}=0.21$ ) than 12 wk (mean $=0.57$ ind . core $e^{-1}, \mathrm{SE}=0.17$ ). The box (time $\times$ treatment) factor was never significant $(p>$ 0.05 ). The time $x$ treatment interaction was only significant for tanaids. Tanaids were significantly more abundant after $6 \mathrm{wk}$ in the $1 \times$ treatment (mean $=$ 1.5 ind. core ${ }^{-1}, \mathrm{SE}=0.42$ ) than in the $0 \times$ treatment $\left(\right.$ mean $=0.66$ ind core $\left.e^{-1}, \mathrm{SE}=0.37\right)$, elevated density 
Table 2. Results of 3-way ANOVA comparing the abundances of common taxa, taxonomic groups, and functional groups among ophiuroid treatments and among boxes and between times for organisms living $0-3 \mathrm{~cm}$ in the sediment. The box (time $\times$ treatment) factor was never significant ( $p \geq 0.05)$ and so is not included. F-value and significance are indicated for main effects and interaction (ns: $\mathrm{p} \geq 0.05 ; \mathrm{p}<0.05, \cdots p<0.01$ )

\begin{tabular}{|c|c|c|c|c|c|c|}
\hline \multirow[t]{2}{*}{ Variable } & \multicolumn{2}{|c|}{ Treatment } & \multicolumn{2}{|c|}{ Time } & \multicolumn{2}{|c|}{ Time $\times$ Treatment } \\
\hline & $F$-value & Sig. & $F$-value & Sig. & F-value & Sig. \\
\hline Chaetozone setosa & 1.99 & ns & 0.37 & ns & 0.15 & $\mathrm{~ns}$ \\
\hline Cossura longocirrata & 1.17 & ns & 0.62 & ns & 0.57 & ns \\
\hline Exogone verugera & 1.36 & ns & 0.04 & ns & 0.30 & ns \\
\hline Mediomastus filiformis & 0.71 & ns & 0.94 & ns & 1.41 & ns \\
\hline Mugga wahrbergi & 0.92 & $\mathrm{~ns}$ & 0.23 & ns & 1.25 & ns \\
\hline Pholoe minuta & 0.44 & ns & 0.11 & ns & 0.68 & ns \\
\hline Prionospio malmgreni & 0.39 & ns & 1.47 & $\mathrm{~ns}$ & 1.31 & ns \\
\hline Pseudopolydora paucibranchiata & 0.67 & ns & 0.01 & ns & 0.02 & ns \\
\hline Schistomeringos sp. & 2.11 & ns & 4.02 & ns & 0.33 & ns \\
\hline Sphaerosyllis tetralis & 1.18 & ns & 0.41 & ns & 0.35 & ns \\
\hline Halacaridae & 0.25 & ns & 0.42 & ns & 1.08 & ns \\
\hline Ostracoda & 0.37 & ns & 0.42 & ns & 1.08 & ns \\
\hline Priapulida & 2.59 & ns & 10.42 & $\because$ & 2.03 & ns \\
\hline Tanaidacea & 1.05 & ns & 0.24 & ns & 3.93 & $\cdot$ \\
\hline Bivalvia & 0.13 & ns & 0.29 & ns & 0.07 & ns \\
\hline Crustacea & 0.45 & ns & 0.28 & ns & 1.00 & ns \\
\hline Polychaeta & 3.68 & $\cdot$ & 0.56 & ns & 1.63 & ns \\
\hline$S f c, D f, S$ & 2.83 & $\cdot$ & 0.15 & ns & 0.56 & ns \\
\hline SfC, C, M & 1.47 & ns & 1.36 & ns & 0.97 & ns \\
\hline Sub, Df, M & 2.11 & ns & 0.71 & ns & 1.16 & ns \\
\hline Sub, C, M & 1.02 & ns & 6.34 & $\cdot$ & 1.57 & ns \\
\hline Sub, Df, S & 0.94 & ns & 0.36 & ns & 1.03 & ns \\
\hline $\mathrm{Sf}, \mathrm{Su}, \mathrm{S}$ & 2.05 & ns & 0.18 & ns & 0.70 & ns \\
\hline Total & 1.51 & ns & 0.07 & ns & 0.31 & ns \\
\hline
\end{tabular}

treatment $\left(\right.$ mean $=0.44$ ind . core ${ }^{-1}, \mathrm{SE}=0.17$ ), or the control (mean $=0.66$ ind . core ${ }^{-1}, \mathrm{SE}=0.23$ ) which were not significantly different from each other. There was no significant difference in the density of tanaids among treatments after $12 \mathrm{wk}$. Ophiuroids had no effects on the abundances of infauna living $3-6 \mathrm{~cm}$ in the sediment and sampled after $12 \mathrm{wk}$ of the experiment (Table 3).

Nonmetric multidimensional scaling (MDS) revealed some groupings by treatment, but the divi-

Fig. 1. Effect of ophiuroid addition and removal on the abundances of taxa and functional groups (see Table 1 for description of functional groups) collected in the top $3 \mathrm{~cm}$ of the sediment and with a significant treatment effect in the ANOVA: mean number $(+\mathrm{SE})$ of individuals per $13.2 \mathrm{~cm}^{2}$ core for $0 \times$ (ophiuroid removal), $1 \times$ (ophiuroid addition at natural density), $\mathrm{C}$ (unmanipulated control), and $\mathrm{H}$ (ophiuroid addition at elevated density) treatments. Student-Newman-Keuls test was used to determine significant differences among means; means with common underline are not significantly different from each other $(p>0.05)$ sions were not striking and in general there were few discrete groupings by time or treatment. ANOSIM indicated that differences between times were significant at $p=0.115$ and among treatments at $p=0.064$. Samples taken at $12 \mathrm{wk}$ from boxes with elevated ophiuroid densities tended to group together on the MDS plot as did samples collected at 6 and $12 \mathrm{wk}$ from boxes from which ophiuroids had been removed (Fig. 2). Many of the samples from boxes with ambient densities of ophiuroids (1x and control) closely

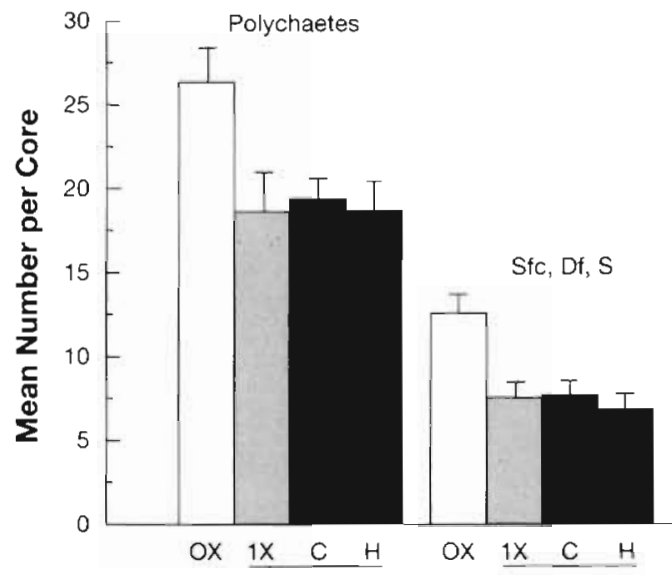


Table 3. Results of 2-way ANOVA comparing the abundances of common taxa, taxonomic groups, and functional groups among treatments and among boxes for organisms living 3 to $6 \mathrm{~cm}$ deep in the sediment and sampled after 12 wk. F-value and significance of treatment and box (treatment) effect are indicated for each group (ns: $p \geq 0.05 ; " p<0.05, \cdots p<0.01$ )

\begin{tabular}{|c|c|c|c|c|}
\hline \multirow[t]{2}{*}{ Variable } & \multicolumn{2}{|c|}{ Treatment } & \multicolumn{2}{|c|}{ Box (Treatment) } \\
\hline & F-value & Sig. & $F$-value & Sig. \\
\hline Chaetozone setosa & 0.32 & ns & 1.05 & ns \\
\hline Cossura longocirrata & 0.82 & ns & 0.94 & ns \\
\hline Exogone verugera & 0.18 & ns & 3.56 & $\because$ \\
\hline Heteromastus filiformis & 1.47 & ns & 0.61 & ns \\
\hline Mediomastus fragilis & 2.45 & ns & 1.95 & ns \\
\hline Paraonis fulgens & 0.62 & ns & 0.64 & ns \\
\hline Paraonis gracilis & 0.89 & ns & 0.86 & ns \\
\hline Pholoe minuta & 0.15 & ns & 0.65 & ns \\
\hline Prionospio cirrifera & 0.74 & $\mathrm{~ns}$ & 1.03 & ns \\
\hline Schistomeningos sp. & 0.16 & ns & 3.03 & $\cdot$ \\
\hline Sosane gracilis & 0.44 & $\mathrm{~ns}$ & 1.00 & $\mathrm{~ns}$ \\
\hline Halacaridae & 1.03 & ns & 0.70 & ns \\
\hline Ostracoda & 1.30 & ns & 2.09 & ns \\
\hline Tanaidacea & 0.50 & ns & 0.77 & ns \\
\hline Bivalvia & 1.16 & ns & 3.06 & $\cdot$ \\
\hline Crustacea & 1.66 & $\mathrm{~ns}$ & 0.55 & ns \\
\hline Polychaeta & 0.73 & ns & 1.02 & ns \\
\hline SfC, Df, S & 0.30 & ns & 2.44 & ns \\
\hline Sfc, C, M & 0.12 & ns & 1.18 & ns \\
\hline Sub, Df, M & 2.05 & ns & 0.87 & ns \\
\hline Sub, C, M & 2.28 & ns & 0.35 & ns \\
\hline Sfc, Su, S & 0.42 & ns & 0.96 & ns \\
\hline Total & 0.46 & ns & 0.96 & ns \\
\hline
\end{tabular}

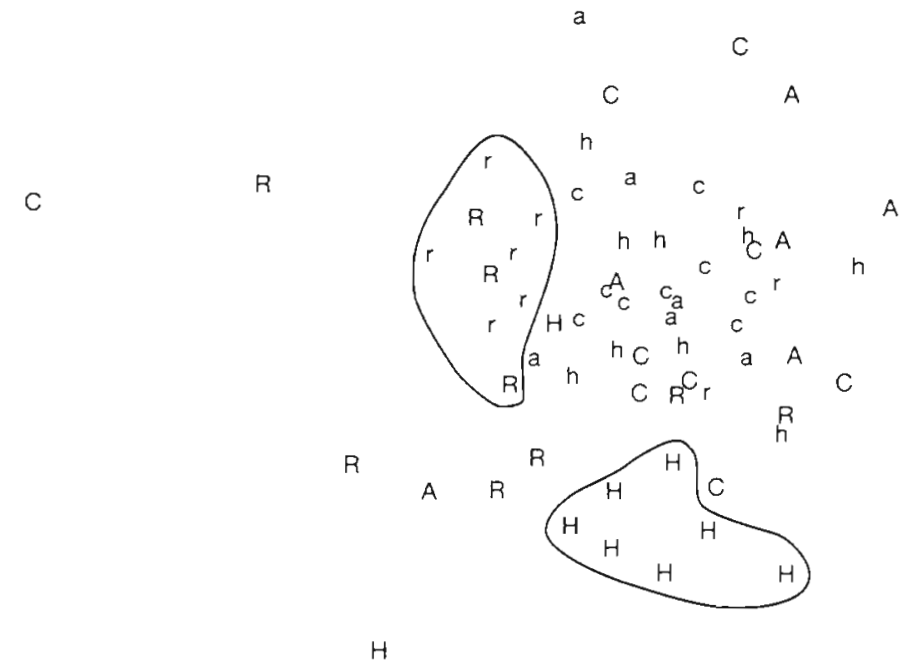

H
Fig. 2. Non-metric multi-dimensional (MDS) plot in 2 dimensions of infaunal abundances in replicate boxes from ophiuroid removal $(R, r)$, ophiuroid addition at natural density $(A, a)$, unmanipualted control $(C, C)$, and ophiuroid addition at elevated density $(H, h)$ after $6 \mathrm{wk}$ (lower-case letter designating treatment) and 12 wk (upper-case letter). Replicates from the same or similar treatment have been grouped together in 2 cases for effect. Species abundances were not transformed and between-sample similarities were calculated with the Bray-Curtis coefficient. Stress for the MDS was 0.28. ANOSIM indicated differences between times were significant at $p=0.115$ and among treatments within time at $p=0.064$ 
Table 4. Mean (SE) species diversity $\left(H^{\prime}\right)$, evenness $(J)$ and species richness $(S)$ per core per box of ophiuroid removal $(0 \times)$, ophiuroid addition $(\mathrm{H})$ and ambient density $\left(1 \times+\mathrm{C}_{i} 1 \times\right.$ and control treatments combined $)$ for 6 wk and 12 wk periods. Significance of Kruskal-Wallis test is indicated (ns: $p \geq 0.05 ; \cdot p<0.05$ ). When the Kruskal-Wallis test was significant, differences among means were compared using Dunn's test. Means which are not significantly different $(p \geq 0.05)$ are connected by common underline

\begin{tabular}{|c|c|c|c|c|c|c|c|c|}
\hline \multirow[t]{2}{*}{ Measurements } & \multicolumn{4}{|c|}{$6 \mathrm{wk}$} & \multicolumn{4}{|c|}{$12 w \mathrm{k}$} \\
\hline & $0 \times$ & $1 x+C$ & $\mathrm{H}$ & Sig & $0 x$ & $1 \times+C$ & $\mathrm{H}$ & Sig \\
\hline$H^{\prime}$ & $3.71(0.14)$ & $3.78(0.04)$ & $3.81(0.10)$ & ns & $3.60(0.11)$ & $3.43(0.11)$ & $3.06(0.09)$ & $\cdot$ \\
\hline$J$ & $0.79(0.02)$ & $0.83(0.01)$ & $0.82(0.01)$ & ns & $0.76(0.01)$ & $0.79(0.01)$ & $0.69(0.01)$ & ns \\
\hline$S$ & $25.3(0.88)$ & $23.2(1.02)$ & $25.0(1.52)$ & ns & $26.3(1.45)$ & $20.8(1.93)$ & $21.0(0.73)$ & ns \\
\hline
\end{tabular}

resembled each other, falling together on the MDS plot.

There was no significant difference in species diversity, evenness, or species richness among treatments after $6 \mathrm{wk}$, but after $12 \mathrm{wk}$ there was a significant difference in species diversity among treatments (Table 4). The ophiuroid removal treatment had a significantly higher Shannon-Wiener Index than the elevated ophiuroid density treatment, with the ambient ophiuroid density treatment intermediate.

\section{Sediment traps}

Ophiuroids had a large and significant effect on the amount of sediment collected in sediment traps after 3 and $8 \mathrm{~d}$. The 2-way ANOVA comparing the weight of sediment collected in traps was highly significant for both treatment $(F=11.00, \mathrm{df}=3,14, \mathrm{p}<0.0006)$ and time $(F=53.6, \mathrm{df}=1,14, \mathrm{p}<0.0001)$, but the time $x$ treatment interaction was not significant $(F=2.24, \mathrm{df}=$ 3,$14 ; \mathrm{p}<0.129$ ). Traps in the $0 \times$ treatment collected significantly less sediment than traps from treatments with ophiuroids (Fig. 3). There was no significant difference among treatments with ophiuroids in the amount of sediment collected in traps.

Fig. 3. Effect of ophiuroid addition and removal on amount of sediment collected in sediment traps. Traps were in place for 3 and $8 \mathrm{~d}$ and the amount of dry weight per trap compared with a 2-way ANOVA. Mean sediment weight $(+\mathrm{SE})$ per trap for both time periods combined is presented for $0 \times$ (ophiuroid removal), $1 \times$ (ophiuroid addition at natural density), C (unmanipulated control), and $\mathrm{H}$ (ophiuroid addition at elevated density) treatments. Student-Newman-Keuls test was used to determine significant differences among means; means with common underline are not significantly different from each other $(p>0.05)$

\section{Stomach contents}

Stomach contents of 12 Ophiura affinis and 30 . albida were examined. Because ophiuroids often regurgitate their stomach contents when handled (Warner 1982), no attempt was made to quantify contents and contents were only examined to confirm the types of food consumed. Five of the stomachs examined were empty. Both species were found to consume harpacticoid copepods, foraminifera, polychaetes, and plant material. Remains (setae and soft parts) of large polychaetes were found in stomachs of both species. The remains of a large terebellid polychaete, Sosane gracilis, were identified from the stomach of an O. affinis.

\section{DISCUSSION}

Ophiura affinis and $O$. albida disturb the sediment surface and consume a wide size range of infaunal organisms. Either of these processes could explain the negative effects these ophiuroids had on infaunal abundances, and it is rarely possible to separate the negative effects of predation and sediment disturbance by soft-bottom predators (but see Kneib 1985, Palmer 1988).

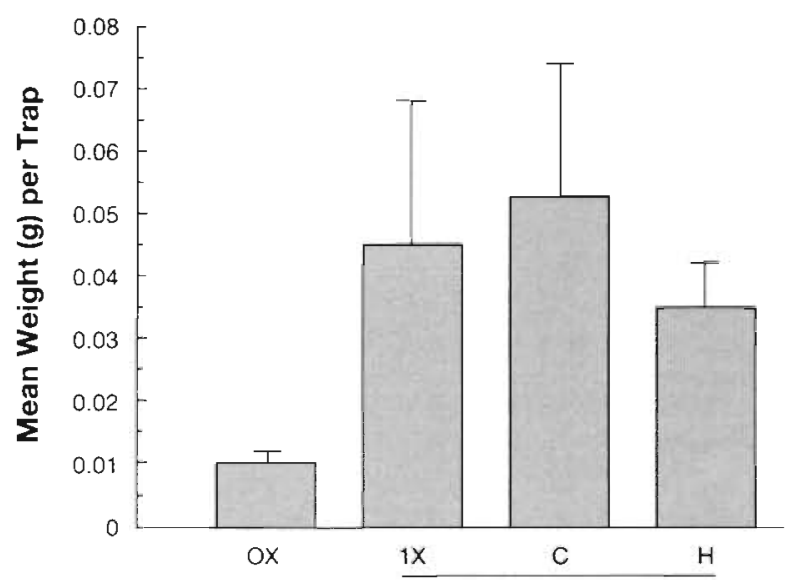


As predicted, these ophiuroids reduced the abundances of surface-dwelling sedentary taxa. The 'Sfc, Df, S' functional group was $40 \%$ less abundant in the presence of ophiuroids than in their absence, although there was no detectable effect on the 'Sfc, Su, S' functional group. Many of the organisms in the 'Sfc, Df, S' group are tube dwellers (e.g. Ampharetidae, Maldanidae, Spionidae, and some Capitellidae) which are particularly susceptible to surface sediment disturbance (Wiltse 1980, Brenchley 1981, Wilson 1981, Hunt et al. 1987). Many of the surface-dwelling organisms, tubiculous and nontubiculous, where extremely small ( $<1 \mathrm{~mm}$ total length), and small organisms tend to be more sensitive to sediment disturbance than large organisms (Brenchley 1981, Wilson 1981). The effect of mobile ophiuroids on infaunal abundances has not been previously investigated, but megafaunal scavengers, including ophiuroids, have been observed to reduce the abundances of nearsurface-dwelling polychaetes in the deep sea (Smith 1986) and high densities of ophiuroids are associated with low abundances of tubiculous polychaetes in some arctic communities (Dale et al. 1989).

All of the significant effects of ophiuroids on infaunal abundances were a consequence of ophiuroid removal rather than addition. Except for the abundance of tanaids during one time period, infaunal densities were never significantly different between ambient ( $1 \times$ and control) and elevated densities of ophiuroids. The same pattern is observed in the sediment trap data. The only significant difference among treatments in amount of sediment collected occurred as a result of the presence or absence of ophiuroids (Fig. 3). Lack of significant difference in sediment collected in traps between ambient and high ophiuroid densities may reflect lower activity of individual ophiuroids at high compared to ambient densities. This reduced activity could explain the lack of significant differences in faunal abundances between ambient and elevated density treatments. The failure to detect differences between ambient and elevated densities in infaunal abundance or sediment movement points out the danger of conducting only addition experiments. In the absence of the removal treatment, the conclusion of this experiment might have been that ophiuroids had no effect on infaunal abundances or sediment movement.

When the densities of all members of the community living in the top $3 \mathrm{~cm}$ of sediment are simultaneously compared between times and among treatments using MDS there is some evidence of differences in community structure between the elevated density treatment sampled at $12 \mathrm{wk}$ and the other treatments (Fig. 2). Community structure in some of the boxes of the ophiuroid removal treatment may also be slightly different from other treatments. These patterns are suggestive, but hardly conclusive, that ophiuroids can cause a change in community structure, and are probably largely determined by the effect of ophiuroids on surface-dwelling infauna, particularly polychaetes, which constitute the majority of taxa in the community.

There is no evidence for competitive exclusion by dominant species and a decline in species diversity following the exclusion of epibenthic predators in softbottom communities (Peterson 1979, Wilson 1991). Predation from infaunal predators and other predators not excluded by cages may help explain the failure of a competitive dominant to become established in response to the removal of epibenthic predators (Ambrose 1984b). The ophiuroid species manipulated in this study appear to reduce diversity (Table 4), which is the same effect epibenthic predators have on diversity (Peterson 1979). Infaunal predators increase infaunal diversity in other systems and the effect of these predators on species diversity is not consistent among communities or predators (Ambrose 1991). Mobile, surface-active ophiurioids may function more like epibenthic predator/disturbers than other infaunal predators which cause minimal sediment disturbance.

The effects of ophiuroids recorded here might be considered modest given the high initial density of ophiuroids in the elevated density treatment and the evidence that they cause substantial sediment disturbance. Many of the taxa in the study community, particularly the mobile ones, may be adapted to the lowlevel, chronic disturbance of ophiuroids. Such an adaptation has been suggested for meiofauna (Alongi 1985). It is also likely that the effects on infaunal densities of manipulating ophiurioids would have been greater had the manipulations occurred in the field with natural recruitment rather than in the mesocosm, where one study demonstrated that larval recruitment to azoic sediment was $90 \%$ lower than in the field (Berge et al. 1986). In the only other manipulation of an ophiuroid in a soft-bottom community, Crowe et al. (1987) found that Aphiura filiformis, which is primarily a suspension feeder, inhibited the recruitment of many infaunal taxa. They concluded that bioturbation had little negative effect on recruitment and most of the effect was a result of ophiuroids ingesting settling larvae and recently settled juveniles.

Aside from apparently reducing the abundance of larvae in the incoming water, there was no evidence of serious artifacts associated with the mesocosm. Only priapulids exhibited a significant difference in density between 6 and $12 \mathrm{wk}$ (Table 2), indicating that conditions in the mesocosm were suitable for maintenance of the community for the 12 wk experiment. Sedimentation rates in the mesocosm are, however, roughly an order of magnitude less than is typical for Norwegian 
fjords (Berge et al. 1986) and the lack of organic input may have modified the ophiuroids' feeding behavior, prompting them to more actively search for food and rely more on predation, as opposed to deposit feeding, than they might normally. Despite its limitations, the Solbergstrand mesocosm has proved a suitable facility for investigations of soft-bottom community structure (Gee et al. 1985, Warwick et al. 1986)

There were also no detectable artifacts resulting from the removal of ophiuroids. Tanaids at 6 wk were the only taxon or functional group with significantly different abundances between the $1 \times$ treatment and the control (Tables $2 \& 3$ ) and replicates from these 2 treatments clustered very closely on the MDS plot (Fig. 2). It was usually possible to remove individual ophiuroids without even touching the sediment surface, but any disturbance of the sediment which did occur was insignificant compared with the disturbance caused by the ophiuroids themselves.

Many of the conclusions concerning the effects of small, infaunal predators on soft-bottom community structure may be biased because very few taxa have been manipulated and most of the effects of these predators have been examined in unvegetated intertidal or shallow subtidal communities (Ambrose 1991). The present study extends our knowledge of the impact of infaunal predators to include 2 species of ophiuroids. Ophiuroids often dominate, at least in terms of biomass, subtidal soft-bottom communities and the results of this study demonstrate that some ophiuroids are potentially important in structuring these communities.

Acknowledgements. This work was funded by a grant from British Petroleum and a fellowship from The Royal Norwegian Council for Scientific and Industrial Research. I am grateful to J. A. Berge and H. P. Leinaas who assisted with field work and K. A. Sandøy who helped in the field and spent many long hours identifying all taxa. G. A. Skilleter was a tremendous help with statistics. I am also grateful to NIVA (Norwegian Institute for Water Research) and T. Bakke for making the Solbergstrand mesocosm facilities available and the University of Oslo, Department of Marine Zoology and Chemistry for providing me additional facilities. I thank the following for valuable discussion and/or comments on the manuscript: T. Bakke, J. A. Commito, J. F. Grassle, J. S. Gray, G. A. Skilleter, K. A. Sandøy and R. Warwick.

\section{LITERATURE CITED}

Abbott, R. T (1974). American seashells, 2nd edn. Van Nostrand, New York

Alongi, D. M. (1985). Effect of physical disturbance on population dynamics and trophic interactions among microbes and meiofauna. J. mar. Res. 43: 351-364

Ambrose, W. G. Jr (1984a). Influences of predatory polychaetes and epibenthic predators on the structure of a soft-bottom community in a Maine estuary. J. exp. mar. Biol. Ecol. 81: 115-145
Ambrose, W. G. Jr (1984b). Role of predatory infauna in structuring marine soft-bottom communities. Mar. Ecol. Prog. Ser. 17: 109-115

Ambrose, W. G. Jr (1991). Are infaunal predators important in structuring marine soft-bottom communities? Am. Zool. 31: $849-860$

Aronson, R. B. (1989). Brittlestar beds: low-predation anachronisms in the British Isles. Ecology 70: 856-865

Baird, D., Evans, P. R., Mile, H. (1985). Utilization by shore birds of benthic production in intertidal areas. Oceanogr mar. Biol. A. Rev. 23: 573-597

Barnes, R. D. (1980). Invertebrate zoology, 4th edn. Saunders College, Philadelphia

Berge, J. A., Schaanning, M., Bakke, T., Sandøy, K., Skeje, G. M., Ambrose, W. G. Jr (1986). A soft-bottom sublittoral mesocosm by the Oslofjord: description, performance and examples of application. Ophelia 26:37-54

Brenchley, G. A. (1981). Disturbance and community structure: an experimental study of bioturbation in marine softbottom environments. J. mar. Res. 39: 767-790

Clark, K. R., Green, R. H. (1988). Statistical design and analysis for a 'biological effects' study. Mar. Ecol. Prog. Ser. 46: 213-226

Crowe, W. A., Josefson, A. B., Svane, I. (1987). Influence of adult density on recruitment into soft sediments: a shortterm in situ sublittoral experiment. Mar. Ecol. Prog. Ser. 41. $61-69$

Dale, J. E., Aitken, A. E., Gilbert, R., Risk, M. J. (1989). Macrofauna of Canadian arctic fjords. Mar. Geol. 85: 331-358

Day, J. H. (1967). A monograph on the Polychaeta of southern Africa. Part 2. Sedentaria. Trustees of The British Museum, London

Fauchald, K., Jumars, P. A. (1979). The diet of worms: a study of polychaete feeding guilds. Oceanogr. mar. Biol. A. Rev. 17: $193-284$

Fujita, T., Ohta, S. (1989). Spatial structure within a dense bed of the brittle star Ophiura sarsi (Ophiruoidae: Echinodermata) in the bathyal zone of Otsuchi, Northeastern Japan. J. oceanogr. Soc. Jap. 45: 289-300

Fujita, T., Ohta, S. (1990). Size structure of dense populations of the brittle star Ophiura sarsii (Ophiuroid: Echinodermata) in the bathyal zone around Japan. Mar. Ecol. Prog. Ser. 64: 113-122

Gee, M. J., Warwick, R. M., Schaaning, M., Berge, J. A., Ambrose, W. G. Jr (1985). Effects of organic enrichment on meiofaunal abundance and community structure in sublittoral soft-sediments. J. exp. mar. Biol. Ecol. 91: 247-262

Gray, J. S. (1981). The ecology of marine sediments. Cambridge Univ Press, Cambridge

Hunt, J.H., Ambrose, W. G. Jr, Peterson, C. H. (1987). Effects of the gastropod Mercenaria mercenaria (L.) on larval settlement and juvenile recruitment of infauna. J. exp. mar. Biol. Ecol. 108: 229-240

Jumars, P. A., Nowell, A. R. M. (1984). Effects of benthos on sediment transport: difficulties with functional grouping Cont. Shelf Res. 3: 115-130

Kneib, R. T. (1985). Predation and disturbance by grass shrimp, Paleomenetes pugio Holthuis, in soft-substratum benthic invertebrate communities. J. exp. mar. Biol. Ecol. 93: $91-102$

Muus, K. (1981). Density and growth of juvenile Amphiura filiformis (Ophiuroidae) in the Øresund. Ophelia 20: $153-168$

Neter, J., Wasserman, W., Kunter, M. H. (1985). Applied linear statistical models. Irwin Press, Homewood

'Olafsson, E., Elmgren, E. (1991). Effects of biological disturbance by benthic amphipods Monoporeia affinis on 
meiobenthic-community structure: a laboratory approach Mar. Ecol. Prog. Ser. 74: 99-107

Palmer, M. A. (1988). Epibenthic predators and marine meiofauna: separating predation, disturbance, and hydrodynamic effects. Ecology 69: 1251-1259

Peterson, C. H. (1979). Predation, competitive exclusion, and diversity in the soft-sediment benthic communities of estuaries and lagoons. In: Livingston, R. J. (ed.) Ecological processes in coastal and marine systems. Plenum Press, New York, p. 233-264

Peterson, C. H. (1991). Intertidal zonation and marine invertebrates in sand and mud. Am. Sci. 79: 236-249

Pettibone, M. H. (1963). Marine polychaete worms of the New England region. I. Aprodithidae through Trochochaetidae. U.S. natl Mus. Bull. 227: 1-356

Posey, M. H. (1987). Influence of relative mobilities on the composition of benthic communities. Mar. Ecol. Prog. Ser. 39: $99-104$

Posey, M.H. (1990). Functional approaches to soft-substrate communities: how useful are they? Rev. aquat. Sci. 2: $343-356$

Reise, K. (1985). Tidal flat ecology. Springer-Verlag, Berlin

Rosenberg, R., Möller, P. (1979). Salinity stratified benthic macrofaunal communities and long-term monitoring along the west coast of Sweden. J. exp. mar. Biol. Ecol. 37 : $175-203$

Smith, C. R. (1986). Nekton falls, low-intensity disturbance and community structure of infaunal benthos in the deepsea. J. mar. Res. 44:567-600

Thorson, G. (1958). Parallel level-bottom communities, their temperature adaptation, and their 'balance' between predators and food animals. In: Buzzati-Traverso, A. A.

This article was submitted to the editor (ed.) Perspectives in manine biology. Univ. California, Berkeley, p. 67-86

Valderhaug, V., Gray, J. S. (1984). Stable macrofauna community structure despite fluctuating food supply in subtidal soft sediments of Oslofjord, Norway. Mar. Biol. 82: $307-322$

Warner, G. F. (1982). Food and feeding mechanism Ophiuroidea. In: Jangoux, M., Lawrence, J. M. (eds.) Echinoderm nutrition. A. A. Belkema, Rotterdam, p. $161-181$

Warwick, R. M., Gee, J. M., Berge, J. A., Ambrose, W. G. Jr (1986). Effects of the feeding activity of the polychaete Streblosoma bairdi (Malmgren) on meiofaunal abundance and community structure. Sarsia 71: 11-16

Wilson, W. H. Jr. (1981). Sediment-mediated interactions in a densely populated infauna assemblage: the effects of the polychaete Abarenicola pacifica. J. mar. Res. 39: $735-748$

Wilson, W. H. Jr (1991). Competition and predation in marine soft-sediment communities. A. Rev. Ecol. Syst. 21: 221-241

Wiltse, W. I. (1980). Effects of Polonices duplicatus (Gastropoda: Naticidae) on infaunal community structure at Barnstable Harbor, Massachusetts, USA. Mar. Biol. 56: $301-310$

Winer, B. J. (1971). Statistical principles in experimental design, 2nd edn. McGraw-Hill, New York

Young, D. K., Rhoads, D. C. (1971). Animal-sediment relations in Cape Cod Bay, Massachusetts. I. A transect study. Mar. Biol. 11: 242-254

Zar, J. H. (1984). Biostatistical analysis. Prentice-Hall, Englewood Cliffs

Manuscript first received February 17, 1993

Revised version accepted: May 4, 1993 